\title{
NF-кB inhibitor on Toll-like receptor 4 signal-induced expression of angiotensinogen and AT1a receptor in neonatal rat left ventricular myocytes
}

\author{
HUA JIANG* ${ }^{*}$, HONG-YAN WANG ${ }^{*}$, JI-WEN WANG, DA-YUAN LOU, NAN NIU, GUI-HUA LI and PENG QU \\ Department of Cardiology, The Second Affiliated Hospital of Dalian Medical University, \\ Dalian, Liaoning 116027, P.R. China
}

Received March 5, 2018; Accepted August 9, 2018

DOI: 10.3892/etm.2018.6697

\begin{abstract}
Effects of toll-like receptor 4 (TLR4)/nuclear factor $-\kappa \mathrm{B}(\mathrm{NF}-\kappa \mathrm{B})$ pathway on expression of angiotensinogen and $\mathrm{AT}_{1 \mathrm{a}}$ receptor were investigated, to explore the role of TLR4/NF- $\kappa$ B signaling pathway in cardiovascular disease. Neonatal rat left ventricular myocytes (NRVMs) were cultured and cardiomyocytes were identified by immunocytochemical staining of sarcomeric $\alpha$-actin. NRVMs were treated with lipopolysaccharide (LPS) at a dose of 10, 100 and 1,000 ng/ml, and RT-PCR was performed $24 \mathrm{~h}$ later to detect the expression of TLR4, angiotensinogen (ATG) and $\mathrm{AT}_{1 \mathrm{a}}$ at mRNA level. NRVMs were cultured and pretreated with caffeic acid phenethylester (CAPE) for $30 \mathrm{~min}$. Then NRVMs were stimulated with LPS $(1,000 \mathrm{ng} / \mathrm{ml})$ for $24 \mathrm{~h}$. Nuclear translocation of NF- $\mathrm{B}$ p 65 was detected by immunocytochemistry. Expression of TLR4, angiotensinogen and $\mathrm{AT}_{1 \mathrm{a}}$ receptor after CAPE stimulation was detected by RT-PCR. TLR4 mRNA was highly expressed in in vitro cultured NRVMs, and the expression level was significantly increased by LPS $(10-1,000 \mathrm{ng} / \mathrm{ml})$ stimulation in a dose-dependent manner $(\mathrm{P}<0.05)$. LPS stimulation also significantly increased the expression levels of angiotensinogen and $\mathrm{AT}_{1 \mathrm{a}}$ receptor in a dose-dependent manner $(\mathrm{P}<0.05)$. NF- $\kappa \mathrm{B}$ was activated and nuclear translocation of NF- $\kappa \mathrm{B}$ p65 occurred after stimulation with LPS $(1,000 \mathrm{ng} / \mathrm{ml})$ for $24 \mathrm{~h}$, while CAPE $(20 \mu \mathrm{g} / \mathrm{ml})$ inhibited the nuclear translocation of NF- $\mathrm{B}$ p 65 and inhibited LPS-induced expression of angiotensinogen and $\mathrm{AT}_{1 \mathrm{a}}$ receptor. With LPS stimulation, TLR4 signaling positively regulates the expression of TLR4 and upregulates the expression of angiotensinogen and $\mathrm{AT}_{1 \mathrm{a}}$ receptor in NRVMs. CAPE, an inhibitor
\end{abstract}

Correspondence to: Dr Peng Qu, Department of Cardiology, The Second Affiliated Hospital of Dalian Medical University, 467 Zhongshan Road, Shahekkou, Dalian, Liaoning 116027, P.R. China E-mail: qqn8dd@163.com; qupeng777@aliyun.com

"Contributed equally

Key words: toll-like receptor 4, renin-angiotensinogen, cardiomyocytes, lipopolysaccharide of NF- $\kappa \mathrm{B}$, inhibited NF- $\mathrm{B}$ p65 activation and inhibited the upregulation of TLR4, angiotensinogen and $\mathrm{AT}_{1 \mathrm{a}}$ receptors induced by LPS. These results suggest that NF- $\kappa \mathrm{B}$ plays a key regulatory role in the above-mentioned effects induced by LPS. Intervention with TLR4/NF- $\kappa \mathrm{B}$ signaling may become a new target for prevention and treatment of cardiovascular diseases.

\section{Introduction}

In 1997, Medzhitov et al (1) discovered the first human Toll protein, which is toll like receptor 4 (TLR4), and confirmed the presence of TLR4/ nuclear factor- $\kappa \mathrm{B}(\mathrm{NF}-\kappa \mathrm{B})$ signaling in human. TLR4/NF- $\kappa \mathrm{B}$ is the main pathway mediating the signal transduction of bacterial lipopolysacchride (LPS), and is also highly expressed in the heart tissue $(2,3)$. After binding to ligand, TLR4 can activate MAPK and NF- $\mathrm{BB}$, so as to regulate inflammation and immune-related gene expression (4). In an animal model of cardiac hypertrophy induced by aortic ligation, it was found that the TLR4 gene-deficient mice had significantly lower cardiac index (cardiac weight/body weight) and smaller size of cardiomyocytes comparing with wild-type mice. Moreover, blocking TLR4/NF- $\kappa \mathrm{B}$ signaling pathway significantly improved cardiac hypertrophy and cardiomyocyte apoptosis induced by stress load, and reduced the sensitivity of myocardial cells to inflammatory reactions, which in turn improved cardiac function $(5,6)$. Therefore, it is hypothesized that TLR4 and its signaling pathways may participate in the occurrence and development of left ventricular remodeling by activating primary immune mechanisms and inflammatory responses in impaired myocardium. But this hypothesis remains to be confirmed. Myocardial local RAS plays an important role in the occurrence and development of ventricular remodeling. Angiotensin II (Ang II) is a major effector of the renin angiotensinogen system (RAS), and as a proinflammatory mediator, and Ang II mainly performs its function through $\mathrm{AT}_{1 \mathrm{a}}$ receptor (7). Studies have shown that TLR4 can sensitively respond to Nak levels of LPS to induce cardiomyocyte apoptosis, and RAS system blockers can completely inhibit LPS-induced cardiomyocyte apoptosis both in vitro and in vivo $(8,9)$, suggesting TLR4-mediated signaling may be related to renin-angiotensinogen system 
in the myocardium. LPS from Escherichia coli can specifically agonize TLR4 without activating other toll-like receptors (10). In this study, cultured neonatal rat left ventricular myocytes (NRVMs) were stimulated with LPS, a specific agonist of TLR4, to activate TLR4/NF- $\kappa$ B signaling pathway. At the same time, NRVMs were treated with caffeic acid phenethylester (CAPE), a specific inhibitor of $N F-\kappa B$, to explore the effects of TLR4/NF- $\kappa \mathrm{B}$ signaling pathway on the expression of angiotensinogen (ATG) and $\mathrm{AT}_{1 \mathrm{a}}$ receptor, so as to explore the mechanism of the role of TLR4/NF- $\kappa$ B in cardiovascular diseases. This study was approved by the Ethics Committee of the Second Affiliated Hospital of Dalian Medical University (Dalian, China).

\section{Materials and methods}

Experimental subjects and main reagents. Healthy newborn Sprague-Dawley rats (10 rats each time, either male or female) aged 6-24 h were provided by the Experimental Animal Center of Dalian Medical University. The newborn rats were kept in cage, temperature $20-24^{\circ} \mathrm{C}$, access to breat milk, relative humidity 40-60\%. LPS (055: B5), CAPE, type II collagenase, trypsin and 5-bromodeoxyuridine (Brdu) were provided by Sigma-Aldrich (Merck KGaA, Darmstadt, Germany). TRIzol was from Gibco; Thermo Fisher Scientific, Inc. (Waltham, MA, USA). Reverse transcription kit was from Takara (Dalian, China). DMEM medium was from Gibco; Thermo Fisher Scientific, Inc. Mouse striated muscle-specific sarcomeric $\alpha$-actin monoclonal antibody (cat. no. MA1-26928), and SABC immunohistochemistry kit including biotinylated secondary antibody, hydrogen peroxide, blocking serum, ultra-sensitive ABC peroxidase mouse $\mathrm{IgG}$ staining kit (cat. no.32052), all from Thermo Fisher Scientific, Inc. Rabbit anti-mouse $\mathrm{NF}-\kappa \mathrm{B}$ p65 monoclonal antibody (cat. no. SC8008) was from Santa Cruz Biotechnology, Inc. (Dallas, TX, USA).

Primary cardiomyocyte culture and grouping. Ventricles were collected from Sprague-Dawley rats, and were cut into pieces. Then $0.1 \%$ trypsin and $0.1 \%$ type II collagenase was added to make single cell suspension, and cardiac fibroblasts and epithelial cells were removed by differential adherence method. During the first $48 \mathrm{~h}$ of cell culture, $0.1 \mathrm{mmol} / 1 \mathrm{Brdu}$ was added to inhibit the proliferation of cells except cardiomyocytes. Cardiomyocytes showed radial or spiral-shaped adherent growth, and obvious cardiomyocytes pulsation was observed $36 \mathrm{~h}$ later. Medium was changed at $48 \mathrm{~h}$, and sub-fusion state was reached at $96 \mathrm{~h}$, then cells were cultured with serum-free DMEM. After incubation for another $24 \mathrm{~h}$, different interventions were performed. Cells were divided into different groups: Experiment I: i) Control group: No intervention factor was added into DMEM medium; ii) LPS $10 \mathrm{ng} / \mathrm{ml}$ group: DMEM medium was added with LPS to a final concentration of $10 \mathrm{ng} / \mathrm{ml}$ and iii) LPS $100 \mathrm{ng} / \mathrm{ml}$ group: DMEM medium was added with LPS to final concentration of $1,000 \mathrm{ng} / \mathrm{ml}$. Intervention was performed for $24 \mathrm{~h}$, and cells were collected. Then expression of TLR4, ATG and $\mathrm{AT}_{1 \mathrm{a}}$ receptor at mRNA level was detected by RT-PCR. Experiment II: i) Control group: No intervention factor was added into DMEM medium; ii) LPS 1,000 ng/ml group: DMEM medium was added with LPS to a final concentration of 1,000 ng/ml; and iii) LPS 1,000 ng/ml + CAPE $20 \mu \mathrm{g} / \mathrm{ml}$ group: CAPE was added to a final concentration of $20 \mu \mathrm{g} / \mathrm{ml}$, and LPS was added to a final concentration of $1 \mu \mathrm{g} / \mathrm{ml} 30 \mathrm{~min}$ later. Cells were treated for $24 \mathrm{~h}$, and expression of TLR4, ATG and $\mathrm{AT}_{1 \mathrm{a}}$ receptor at mRNA level was detected by RT-PCR. Each experiment was repeated 3 times.

Identification of cardiomyocytes. Cardiomyocytes were seeded on glass slides and observed under an inverted microscope (Olympus Corporation, Tokyo, Japan). Cells were radial and swirling shape with transparent cytoplasm and oval nuclei in the center. After incubation for $96 \mathrm{~h}$, slides were fixed with $4 \%$ paraformaldehyde for $20 \mathrm{~min}$. After washing with PBS 3 times, slides were immersed in $1 \%$ triton solution for 5 min. SABC chemical staining was performed with striated muscle-specific sarcomeric $\alpha$-actin monoclonal antibody (cat. no. ZM-0001) to identify cardiomyocytes.

Immunocytochemistry analysis of $N F-\kappa B$ activation. Density of NRVMs was adjusted to $1 \times 10^{6}$ cells $/ \mathrm{ml}$, and cells were seeded on cell culture plates covered with cover glasses. After treatment for $24 \mathrm{~h}$, cover glasses were removed, and plates were washed with PBS and fixed with $1 \%$ paraformaldehyde ( $\mathrm{pH} 7.0$ ) at room temperature for $30 \mathrm{~min}$ and $0.1 \%$ Triton $\mathrm{X}-100(\mathrm{pH} 7.0)$ at room temperature for $5 \mathrm{~min}$. Rabbit anti-mouse NF- $\mathrm{B}$ p65 antibody (cat. no. SC8008; Santa Cruz Biotechnology, Inc.) was added with a ratio of $1: 100$ and incubated at $37^{\circ} \mathrm{C}$ for $60 \mathrm{~min}$. Biotin-avidin reaction system was used to detect the immune response. After DAB colorimetry and hematoxylin counterstaining, slides were sealed. Immunocytochemistry results were determined according to the following criteria: $\mathrm{NF}-\kappa \mathrm{B}$ exists in the cytoplasm under normal circumstances, and enters nucleus after activation. So, positive expression of $\mathrm{NF}-\kappa \mathrm{B}$ in nucleus indicates the activation. Five visual fields were randomly selected under the 200-fold optical microscope and the activation of $\mathrm{NF}-\kappa \mathrm{B}$ was assessed by calculating the percentage of positive cells.

Detection of TLR4, AT $T_{1 a}$ receptor and ATG $m R N A$ expression in cardiomyocytes. Primers were synthesized by Takara. Total RNA was extracted by using TRIzol reagent according to the instructions. The quality of RNA samples was detected, and only the ones with OD260/OD280 ratio between 1.6 and 1.8 were used in reverse transcription. TLR4, $\mathrm{AT}_{1 \mathrm{a}}$ receptor and ATG expression were detected by two step method. Reverse transcription conditions: $30^{\circ} \mathrm{C}$ for $10 \mathrm{~min}, 50^{\circ} \mathrm{C}$ for $30 \mathrm{~min}$ and $99^{\circ} \mathrm{C}$ for $5 \mathrm{~min}$. Primers used in PCR reaction were: $5^{\prime}-\mathrm{CGCT}$ TTCAGCTTTGCCTTCATTAC-3' (sense) and 5'-AGCTACT TCCTTGTG CCCTGTGAG-3' (antisense) for TLR4, length of amplified fragment was 555 bp; 5'-TTCAGGCCAAGAC CTCC-3' (sense) and 5'-CCAGCCGGGAGGTGCAGT-3' (antisense) for ATG, length of amplified fragment was $308 \mathrm{bp}$; 5'-GCACACTGGCAATGT AATGC-3' (sense) and 5'-GTTG AACAGAACAAG TGACC-3' (antisense) for $\mathrm{AT}_{1 \mathrm{a}}$, length if amplified fragment was 385 bp; 5'-GTGGACGTTTATTGAC TTCGG-3' (sense) and 5'-TTCTT TGCTTTGCCTTTGC-3' (antisense) for $\beta$-MHC, length of amplified fragment was 399 bp; 5'-AACCCTAAGGCCAACCG TGAAAAG-3' (sense) and 5'-TCATGAGGTAGTCTGTCAT-3' (antisense) for endogenous control $\beta$-actin, length of amplified fragment was 


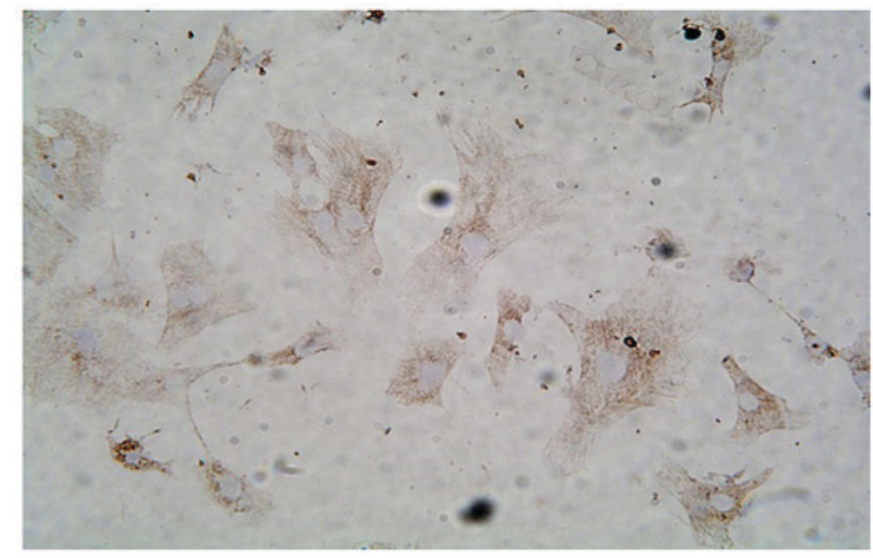

Figure 1. Immunocytochemistry detection of striated muscle-specific sarcomeric $\alpha$-actin $\times 200$. Positive staining of $\alpha$-actin related antigen is a brown particle in the cytoplasm.

241 bp. TLR4 PCR reaction conditions: $94^{\circ} \mathrm{C}$ for $2 \mathrm{~min}$, then 30 cycles of $94^{\circ} \mathrm{C}$ for $30 \mathrm{sec}, 60^{\circ} \mathrm{C}$ for $60 \mathrm{sec}$ and $72^{\circ} \mathrm{C}$ for $1.5 \mathrm{~min}$, and $72^{\circ} \mathrm{C}$ for $10 \mathrm{~min}$. ATG PCR reaction conditions: $94^{\circ} \mathrm{C}$ for $2 \mathrm{~min}$, then 30 cycles of $94^{\circ} \mathrm{C}$ for $30 \mathrm{sec}, 63^{\circ} \mathrm{C}$ for $60 \mathrm{sec}$ and $72^{\circ} \mathrm{C}$ for $1.5 \mathrm{~min}$, and $72^{\circ} \mathrm{C}$ for $10 \mathrm{~min}$. $\mathrm{AT}_{1 \mathrm{a}}$ receptor PCR reaction conditions: $94^{\circ} \mathrm{C}$ for $2 \mathrm{~min}$, then 30 cycles of $94^{\circ} \mathrm{C}$ for $30 \mathrm{sec}, 58^{\circ} \mathrm{C}$ for $45 \mathrm{sec}$ and $72^{\circ} \mathrm{C}$ for $1.5 \mathrm{~min}$, and $72^{\circ} \mathrm{C}$ for $10 \mathrm{~min}$. PCR products were electrophoresed on a $1.5 \%$ agarose gel and results were photographed with a gel imager. The ratio of the gray value of target gene to the gray value of $\beta$-actin band was taken as the relative expression level of target mRNA.

Statistical analysis. Data were processed by using SPSS 11.5 statistical software (SPSS, Inc., Chicago, IL, USA). Each experiment was performed 3 times, and the data are expressed as mean \pm standard deviation (mean \pm SD) and analyzed by one-way ANOVA. Comparison between the groups was made by analyzing data with Least Significant Difference method. $\mathrm{P}<0.05$ was considered to be statistically significant.

\section{Results}

Culture and identification of cardiomyocytes (NRVMs). Fibroblasts were removed by using differential adherence method. Cells were cultured for $24 \mathrm{~h}$, and cells showed long rod, polygon or fusiform shapes with concentric or radial growth. Myocardial cell-specific synchronized beats were observed at $48 \mathrm{~h}$. Immunocytochemistry detection of striated muscle-specific sarcomeric $\alpha$-actin was used to identify cardiomyocytes, and the purity of $>95 \%$ (Fig. 1).

Results of cell viability assay. Cell viability was determined by trypan blue staining and cell counting. The treatment factors used in this study had no obvious effects on the growth of cardiomyocytes, and the cell survival rate was over $95 \%$.

LPS upregulates the expression of TLR4 mRNA in NRVMs. RT-PCR analysis showed that the expression of TLR4 mRNA in cardiomyocytes was relatively high. Compared with the control group (TLR4 absorbance value was $0.301 \pm 0.112$ ), TLR4 mRNA expression was significantly increased after treatment with LPS for $24 \mathrm{~h}$ in a dose-dependent manner (LPS 10, 100 and $1,000 \mathrm{ng} / \mathrm{ml}$, TLR 4 absorbance. Values were $0.651 \pm 0.162$, $0.801 \pm 0.217$ and $1.052 \pm 0.227$, respectively, $\mathrm{F}=26.2, \mathrm{P}<0.01$ ). Compared with control group (TLR4 absorbance value was $0.301 \pm 0.112$ ), treatment with 10,100 and $1,000 \mathrm{ng} / \mathrm{ml}$ of LPS for $24 \mathrm{~h}$ increased the expression level of TLR 4 by $1.17,1.67$ and 2.5 times, respectively (Fig. 2).

LPS upregulated the expression of ATG mRNA in NRVMs. RT-PCR analysis showed that the expression level of angiotensinogen mRNA was relatively low in cardiomyocytes. Compared with control group (ATG absorbance values was $0.101 \pm 0.121$ ), expression of angiotensinogen mRNA was significantly increased in NVMCs after LPS stimulation for $24 \mathrm{~h}$ in a dose-dependent manner (LPS 10, 100 and $1,000 \mathrm{ng} / \mathrm{ml}$, ATG absorbance values were $0.311 \pm 0.162$, $0.511 \pm 0.179$ and $0.651 \pm 0.209$, respectively, $\mathrm{F}=28.9, \mathrm{P}<0.01)$. Compared with control group (ATG absorbance value was
A

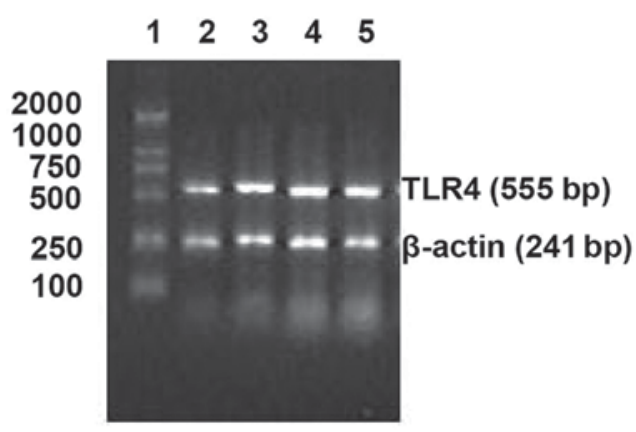

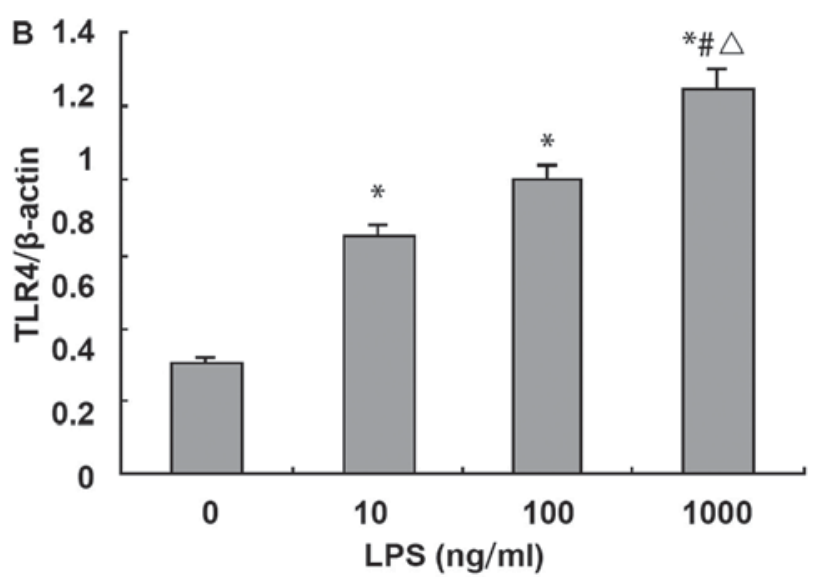

Figure 2. LPS upregulates TLR4 mRNA expression in NRVMs. (A) Agarose gel electrophoresis of TLR4 and $\beta$-actin PCR amplification products: 1, DNA marker, 100, 250, 500, 750, 1,000 and 2,000 bp (from bottom to top); 2, normal control group; 3, LPS $10 \mathrm{ng} / \mathrm{ml} ; 4$, LPS $100 \mathrm{ng} / \mathrm{ml}$; and 5, LPS 1,000 ng/ml. (B) Absorbance value of TLR4 and $\beta$-actin PCR amplification bands $(\mathrm{n}=3)$. ${ }^{*} \mathrm{P}<0.01$ compared with control group; ${ }^{*} \mathrm{P}<0.01$ compared with $\mathrm{LPS} 10 \mathrm{ng} / \mathrm{ml}$; ${ }^{\Delta} \mathrm{P}<0.05$ compared with LPS $100 \mathrm{ng} / \mathrm{ml}$. 
A

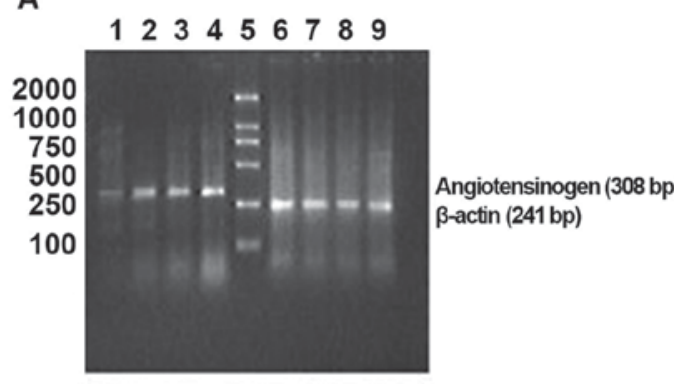

B

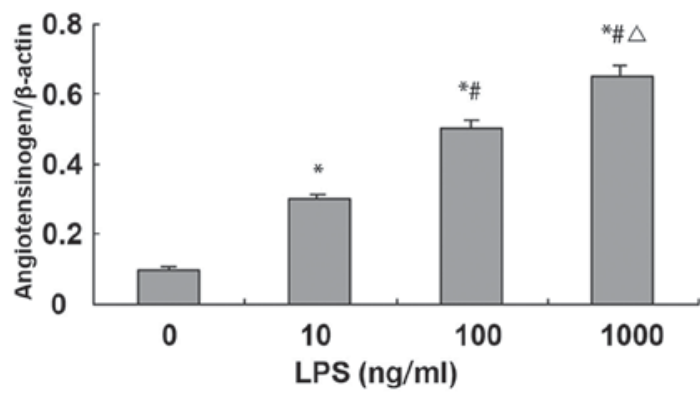

Figure 3. LPS upregulates ATG mRNA expression in NRVMs. (A) Agarose gel electrophoresis of ATG and $\beta$-actin PCR amplification products: 1-4, agarose gel electrophoresis of ATG PCR amplification products: 1, normal control group; 2, LPS $10 \mathrm{ng} / \mathrm{ml} ; 3$, LPS $100 \mathrm{ng} / \mathrm{ml} ; 4$, LPS 1,000 ng/ml; 5, DNA marker, 100 , $250,500,750,1,000$ and 2,000 bp (from bottom to top); and 6-9, agarose gel electrophoresis of $\beta$-actin PCR amplification products. (B) Absorbance value of ATG and $\beta$-actin PCR amplification bands $(\mathrm{n}=3)$. ${ }^{*} \mathrm{P}<0.01$ compared with control group; ${ }^{*} \mathrm{P}<0.01$ compared with $\mathrm{LPS} 10 \mathrm{ng} / \mathrm{ml} ;{ }^{\wedge} \mathrm{P}<0.05$ compared with LPS $100 \mathrm{ng} / \mathrm{ml}$.
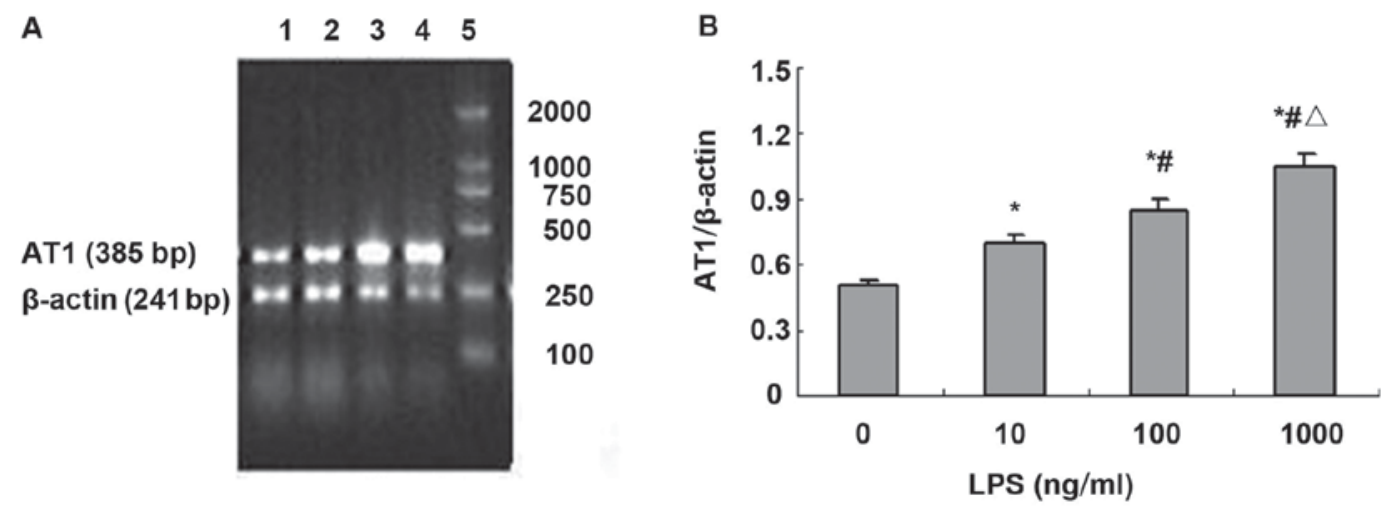

Figure 4. LPS upregulates $\mathrm{AT}_{\mathrm{la}} \mathrm{mRNA}$ expression in NRVMs. (A) Agarose gel electrophoresis of TLR4 and $\beta$-actin PCR amplification products: 1, normal control group; 2, LPS $10 \mathrm{ng} / \mathrm{ml}$; 3, LPS $100 \mathrm{ng} / \mathrm{ml}$; 4, LPS 1,000 ng/ml; and 5, DNA marker, 100, 250, 500, 750, 1,000 and 2,000 bp (from bottom to top) (B) Absorbance value of TLR4 and $\beta$-actin PCR amplification bands $(\mathrm{n}=3)$. ${ }^{*} \mathrm{P}<0.01$ compared with control group; ${ }^{\text {"P }}<0.01$ compared with LPS 10 ng/ml; ${ }^{\Delta} \mathrm{P}<0.05$ compared with LPS $100 \mathrm{ng} / \mathrm{ml}$.

$0.101 \pm 0.121$ ), treatment with 10,100 and $1,000 \mathrm{ng} / \mathrm{ml}$ of LPS for $24 \mathrm{~h}$ increased the expression level of ATG 2, 4 and 5.5 times, respectively (Fig. 3).

LPS upregulates of $A T_{\text {Ia }}$ receptor mRNA expression in NRVMs. RT-PCR analysis showed that, compared with the control group (TLR4 absorbance value was $0.501 \pm 0.141$ ), expression level of $\mathrm{AT}_{1 \mathrm{a}}$ receptor mRNA in cardiomyocytes was significantly increased in a dose-dependent manner (LPS 10,100 and $1,000 \mathrm{ng} / \mathrm{ml}, \mathrm{AT}_{1 \mathrm{a}}$ receptor absorbance value was $0.701 \pm 0.182,0.851 \pm 0.279$ and $1.051 \pm 0.309$, respectively, $\mathrm{F}=18.9, \mathrm{P}<0.01)$. Compared with control group (TLR4 absorbance value was $0.501 \pm 0.141$ ), treatment with 10,100 and $1,000 \mathrm{ng} / \mathrm{ml}$ of LPS for $24 \mathrm{~h}$ increased the expression level of $\mathrm{AT}_{1 \mathrm{a}}$ receptor mRNA by $0.4,0.7$ and 1.14 times, respectively (Fig. 4).

Effect of NF- $\kappa B$ inhibitor CAPE on LPS-induced activation of $N F-\kappa B$ in NRVMs. Immunocytochemistry staining showed that expression level of NF- $\mathrm{KB}$ p 65 was low. After stimulation with LPS $(1,000 \mathrm{ng} / \mathrm{ml})$ for $24 \mathrm{~h}$, more nuclei showed brownish yellow, indicating the nuclear translocation of NF- $\kappa B$ p 65 after LPS stimulation. There was almost no nuclear staining after treatment with NF- $\mathrm{kB}$ inhibitor CAPE $(20 \mu \mathrm{g} / \mathrm{ml})$, suggesting that CAPE inhibits the activation of NF- $\mathrm{KB}$ by LPS (Fig. 5).

Effect of NF- $\mathrm{BB}$ inhibitor CAPE on LPS-induced TLR4 mRNA expression in NRVMs. Compared with control group, expression level of TLR4 mRNA was significantly increased after treatment with LPS $(1,000 \mathrm{ng} / \mathrm{ml})$ for $24 \mathrm{~h}$ (absorbance value $0.301 \pm 0.112$ vs. $1.052 \pm 0.227, \mathrm{P}<0.01$ ) CAPE $(20 \mu \mathrm{g} / \mathrm{ml})$ inhibited TLR4 mRNA (absorbance value: $1.052 \pm 0.227$ vs. $0.411 \pm 0.123, \mathrm{P}<0.01$ ) (Fig. 6).

Effect of NF- $\kappa B$ inhibitor CAPE on LPS-induced ATG mRNA expression in NRVMs. Compared with control group, LPS $(1,000 \mathrm{ng} / \mathrm{ml})$ stimulation for $24 \mathrm{~h}$ significantly upregulated ATG mRNA expression in NRVMs (absorbance value $0.101 \pm 0.112$ vs. $0.652 \pm 0.227, \mathrm{P}<0.01)$. CAPE $(20 \mu \mathrm{g} / \mathrm{ml})$ inhibited ATG mRNA expression (absorbance value: $0.652 \pm 0.227$ vs. $0.191 \pm 0.123, \mathrm{P}<0.01$ ) (Fig. 7 ).

$N F-\kappa B$ inhibitor CAPE regulates LPS-induced NRVMs $A T_{\text {Ia }}$ receptor $m R N A$ expression. Compared with control group, LPS $(1,000 \mathrm{ng} / \mathrm{ml})$ stimulation for $24 \mathrm{~h}$ significantly upregulated $\mathrm{AT}_{1}$ mRNA expression in NRVMs (absorbance 
A

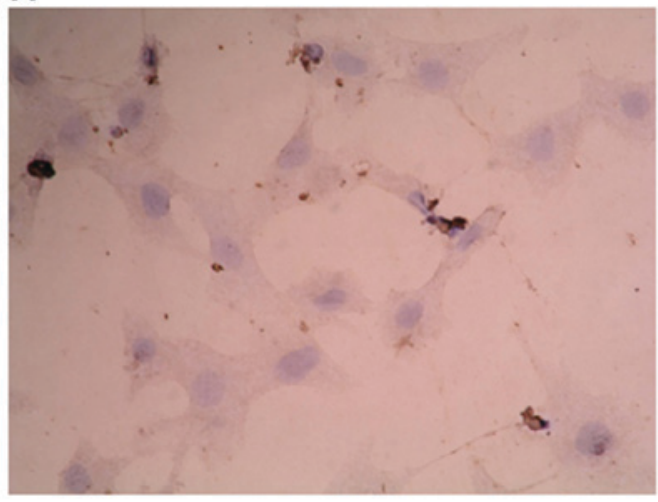

Control group $\times 200$

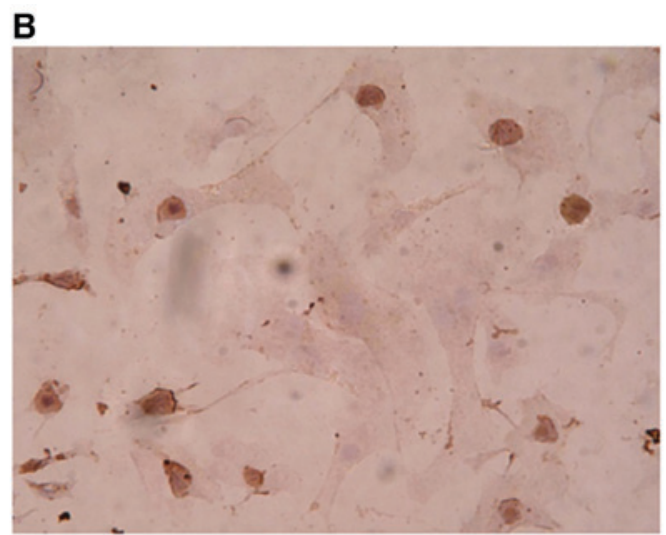

LPS group $\times 200$

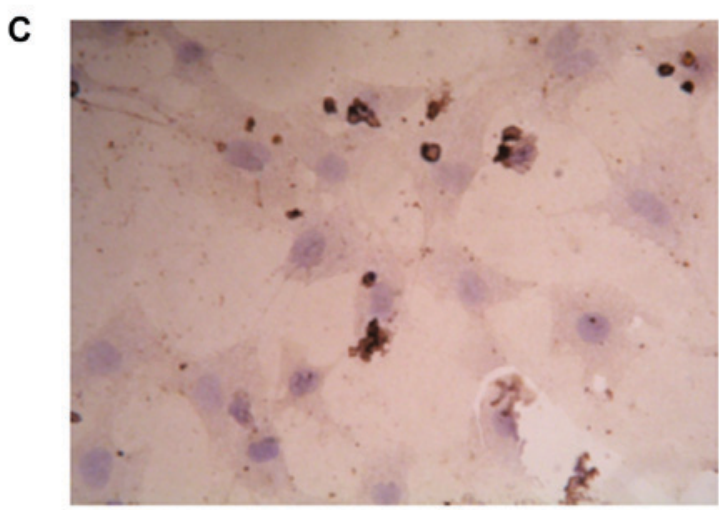

LPS+CAPE group $\times 200$

Figure 5. Nuclear translocation of NF-kB detected by immunohistochemical method. (A) Control group, almost no signal in the nucleus; (B) LPS group, nuclear membrane and nuclear were stained; and (C) LPS+CAPE, almost no signal in the nucleus.
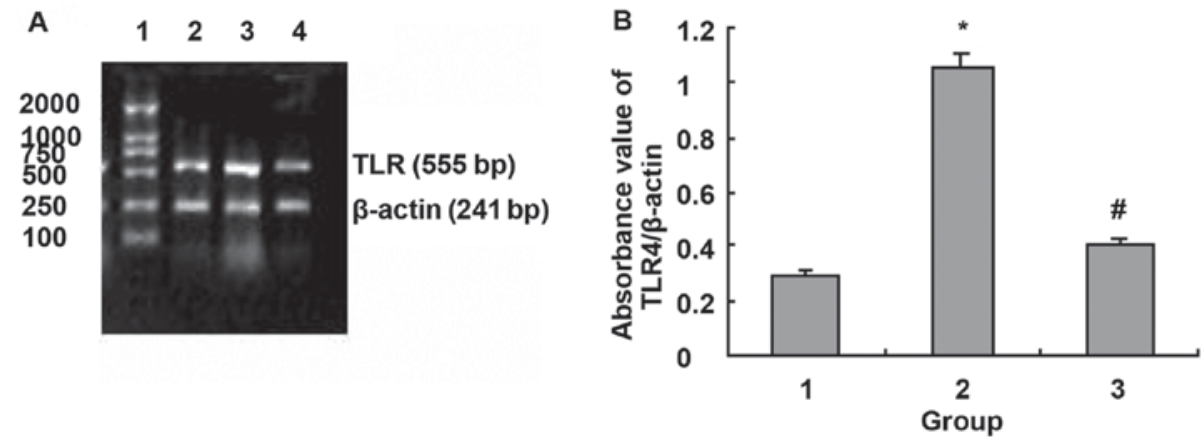

Figure 6. Effects of NF- $\mathrm{kB}$ blocker CAPE on LPS-induced TLR4 mRNA expression. (A) Agarose gel electrophoresis of TLR4 and $\beta$-actin PCR amplification products: 1, DNA marker, 100, 250, 500, 750, 1,000 and 2,000 bp (from bottom to top); 2, normal control group; 3, LPS 1,000 ng/ml; and 4, LPS $1,000 \mathrm{ng} / \mathrm{ml}+$ CAPE $20 \mu \mathrm{g} / \mathrm{ml}$. (B) Absorbance value of TLR4 and $\beta$-actin PCR amplification bands. 1, Normal control group; 2, LPS 1,000 ng/ml; and 3, LPS $1,000 \mathrm{ng} / \mathrm{ml}+\mathrm{CAPE} 20 \mu \mathrm{g} / \mathrm{ml} .{ }^{*} \mathrm{P}<0.01$ compared with control group; ${ }^{*} \mathrm{P}<0.01$ compared with LPS $1,000 \mathrm{ng} / \mathrm{ml}$.

value $0.501 \pm 0.112$ vs. $1.05 \pm 0.227, \mathrm{P}<0.01)$. CAPE $(20 \mu \mathrm{g} / \mathrm{ml})$ inhibited $\mathrm{AT}_{1 \mathrm{a}}$ mRNA expression (absorbance value: $1.05 \pm 0.227$ vs. $0.711 \pm 0.223, \mathrm{P}<0.01)$ (Fig. 8 ).

\section{Discussion}

Recently cloned human TLR4 is a transmembrane receptor that mediates inflammation and the innate immune response. Studies have shown that TLR4 is highly expressed in cardiomyocytes, and TLR4-mediated signaling plays an important role in the pathogenesis of cardiovascular diseases such as heart failure, atherosclerosis, myocarditis and myocardial remodeling (3-5). TLR4 was found to be a portal protein that mediates LPS signaling (10). LPS is the main component cell wall outer membrane of gram-negative bacteria, and is the most common pathogen-associated molecular pattern (PMAPs). In this study, the purified $E$. coli LPS was used as a TLR4 specific agonist to study the effect of TLR4 activation on the renin-ATG in neonatal rat cardiomyocytes. This study found that LPS upregulated TLR4 mRNA expression by agonizing TLR4 in a dose-dependent manner. TLR4 as a transmembrane signal transduction receptor, its expression level directly affects its signal transduction. 
A

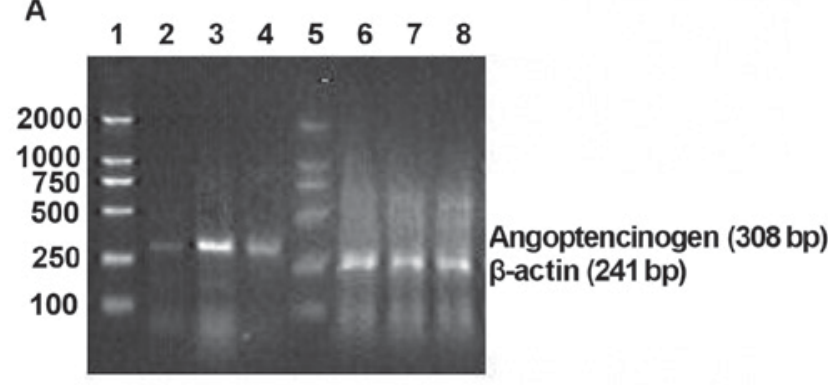

B

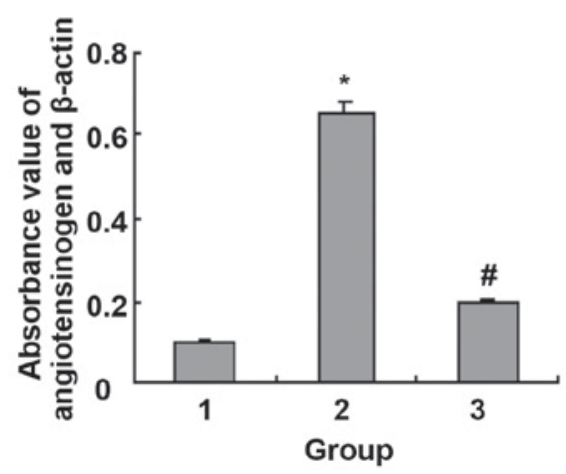

Figure 7. NF- $\kappa B$ blocker CAPE modulated LPS-induced angiotensinogen mRNA expression. (A) Agarose gel electrophoresis of ATG and $\beta$-actin PCR amplification products: 1, 5, DNA marker, 100, 250, 500, 750, 1,000 and 2,000 bp (from bottom to top); 2-4, ATG PCR amplification products: 2, normal control group; 3, LPS 1,000 ng/ml and; 4, LPS 1,000 ng/ml + CAPE $20 \mu \mathrm{g} / \mathrm{ml} ; 6-8, \beta$-actin PCR amplification products: 6, normal control group; 7, LPS 1,000 ng/ml; and 8, LPS 1,000 $\mathrm{ng} / \mathrm{ml}+$ CAPE $20 \mu \mathrm{g} / \mathrm{ml}$. (B) Absorbance value of angiotensinogen and $\beta$-actin PCR amplification bands: 1 , Normal control group; 2 , LPS $1,000 \mathrm{ng} / \mathrm{ml}$; and 3, LPS $1,000 \mathrm{ng} / \mathrm{ml}+$ CAPE $20 \mu \mathrm{g} / \mathrm{ml}$. "P $<0.01$ compared with control group; ${ }^{\#} \mathrm{P}<0.01$ compared with LPS $1,000 \mathrm{ng} / \mathrm{ml}$.

A

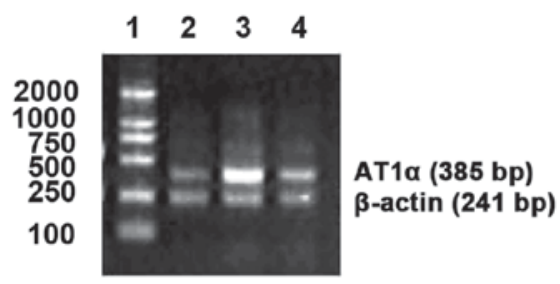

B

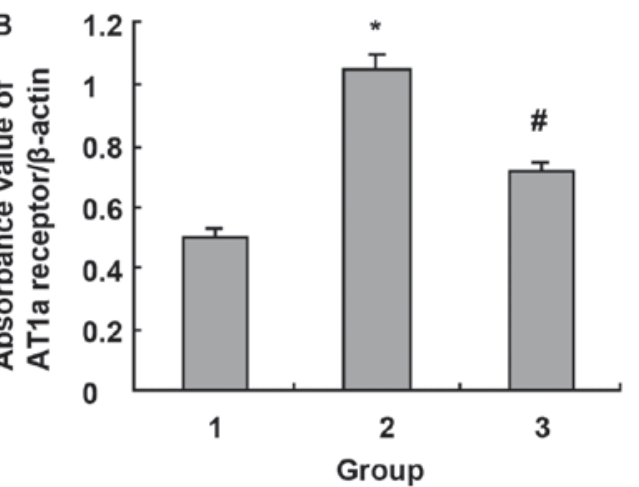

Figure 8. NF-kB blocker CAPE regulated LPS-induced $\mathrm{AT}_{\mathrm{la}}$ receptor mRNA expression. (A) Agarose gel electrophoresis of TLR4 and $\beta$-actin PCR amplification products: 1, DNA marker, 100, 250, 500, 750, 1,000 and 2,000 bp (from bottom to top); 2, normal control group; 3, LPS 1,000 ng/ml; and 4, LPS $1,000 \mathrm{ng} / \mathrm{ml}+$ CAPE $20 \mu \mathrm{g} / \mathrm{ml}$. (B) Absorbance value of $\mathrm{AT}_{\mathrm{la}}$ receptor and $\beta$-actin PCR amplification bands. 1, Normal control group; $2, \mathrm{LPS} 1,000 \mathrm{ng} / \mathrm{ml}$; 3, LPS $1,000 \mathrm{ng} / \mathrm{ml}+$ CAPE $20 \mu \mathrm{g} / \mathrm{ml} .{ }^{*} \mathrm{P}<0.01$ compared with control group; ${ }^{*} \mathrm{P}<0.01$ compared with LPS 1,000 ng/ml.

Upregulation of TLR4 may increase the sensitivity of myocardial cells to injury stimuli. We also found that LPS activated TLR4 and upregulated expression of $\mathrm{ATG}$ and $\mathrm{AT}_{1 \mathrm{a}}$ receptor mRNA in a dose-dependent manner. Therefore, we believe that TLR4 activation mediated the expression of $\mathrm{ATG}$ and $\mathrm{AT}_{1 \mathrm{a}}$ receptor. TLR4 signaling pathway may participate in the occurrence and development of left ventricular remodeling and other cardiovascular diseases by activating the renin-ATG system.

Renin-ATG system in circulating blood rapidly regulates blood pressure, salt metabolism and homeostasis via Ang II. With the development and application of molecular biology techniques, it has been found that there is an independent RAS in the heart, and activation of local myocardial RAS regulates cardiomyocyte growth, proliferation, differentiation and apoptosis (7). ATG is the most basic substance of RAS. ATG produces Ang I and angiotensin-converting enzyme under the action of renin, angiotensin and cathepsin, which in turn degrade Ang I to Ang II, and Ang II can also be produced by a renin-independent ACE-independent pathway. Ang II performs it functions by highly specifically binding to its receptor on cell membrane surface. Almost all known effects of Ang II on inflammatory responses regulation, cell growth (such as tissue fibrosis, hypertrophy, and tissue remodeling) are mediated by
$\mathrm{AT}_{1 \mathrm{a}}$ receptor $(7,11)$. This study showed that TLR4 activation significantly enhanced the expression of angiotensinogen and $\mathrm{AT}_{1}$ receptor, and the 1.17 times increase in expression level of TLR4 was followed by the 2 times increase in expression level of ATG, and the 1.67 times increase in expression level of TLR4 was followed by the 4 times increase in expression level of ATG. At the same time, with the increase in $\mathrm{AT}_{1 \mathrm{a}}$ receptor expression, effect of RAS is further strengthened. RAS constricts vascular smooth muscle, arrests sodium retention, inhibits renin secretion, promotes endothelin secretion, increases vasopressin release, increases blood pressure, activates the sympathetic nervous system, stimulates cardiac hypertrophy, stimulates vascular and cardiac fibrosis, and increases myocardial contractility, induces arrhythmias, activates plasminogen activator inhibitor 1 , stimulates peroxide formation, and participates in almost every aspect of the cardiovascular system via $\mathrm{AT}_{1 \mathrm{a}}$ receptor. Therefore, TLR4 signaling pathway not only plays an important role in left ventricular remodeling, but also has important functions in the occurrence and development of other cardiovascular diseases.

More importantly, most patients with cardiovascular disease show no definite infection factors. In chronic and sub-acute states, such as scaling, smoking, periodontal disease or chronic 
infection and exercise, LPS level in vivo is maintained at $\mathrm{pg} / \mathrm{ml}$ to $\mathrm{ng} / \mathrm{ml}$ level (8). Studies have shown that cardiomyocytes still can sensitively respond to Nak levels of LPS through TLR4; although this response is not enough to cause blood pressure depression, production of TNF- $\alpha$ and interleukin-1 $\beta$ (IL-1 $\beta$ ) and other cardiac myocyte-reactive factors such as endotoxemia, it can induce cardiomyocyte apoptosis (8). Consistent with previous studies, in our study, LPS at the level of $10 \mathrm{ng} / \mathrm{ml}$ still increased the expression of TLR4, ATG and AT1. Moreover, macromolecular degradation products in the body, intracellular components released after cell rupture, and gene products activated by inflammation can activate TLR4 and promote the signal cascade (12). Chronic TLR4 signaling and RAS activation may be a major contributor to progressive dysfunction in target organs. NF- $\kappa \mathrm{B}$ is a group of multidirectional nuclear transcription regulators. In general, $N F-\kappa B$ has two subunits, $\mathrm{p} 50$ and p65, which form heterodimers and exist in the cytoplasm in an inactive form. Inhibitors $\kappa \mathrm{B}$ (I $\kappa \mathrm{Bs}$ ) control the activation of $\mathrm{NF}-\kappa \mathrm{B}$. They bind to $\mathrm{NF}-\kappa \mathrm{B}$ dimers to mask the nuclear localization region of $N F-\kappa B$. Phosphorylation and activation

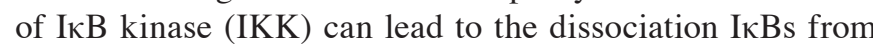
$\mathrm{NF}-\kappa \mathrm{B}$, which in turn activate $\mathrm{NF}-\kappa \mathrm{B}$. Then, NF- $\mathrm{B}$ will translocate from cytoplasm to the nucleus and binds to target genes and regulates a series of target genes involved in cardiovascular pathophysiology, including cytokines, angiotensinogen, and $\mathrm{AT}_{1}$ receptors (13). In this study, nuclear translocation of $\mathrm{NF}-\kappa \mathrm{B}$ p65 was significantly increased in cardiomyocytes after treatment with LPS for $24 \mathrm{~h}$. CAPE inhibited the activation of $\mathrm{NF}-\kappa \mathrm{B}$ p65, and also inhibited the upregulation of expression of ATG and $\mathrm{AT}_{1}$ receptor induced by LPS. Since NF- $\kappa$ B plays an important regulatory role on the expression of angiotensinogen and $\mathrm{AT}_{1}$ receptor genes (12), TLR4/NF- $\mathrm{BB}$ pathway is thought to mediate upregulation of the expression of ATG and $\mathrm{AT}_{1 \mathrm{a}}$ receptor induced by LPS in NRVMs, and NF- $\kappa$ B plays a key regulatory role in TLR4-mediated effects described above.

It has been reported that the antioxidant PDTC downregulates the increased expression of TLR4 induced by LPS and IL-1 $\beta$ in both cardiomyocytes and microvascular endothelial cells, and PDTC also downregulates TLR4 expression in normal cardiomyocytes (2). An et al (14) showed that TLR4 expression is dependent on NF- $\kappa \mathrm{B}$ activation. Previous studies have shown that changes in TLR4 expression on the cell surface directly alter the response of cells to LPS. Harju et al (15) injected LPS into the amniotic membrane of mice at different stages of pregnancy. Expression of TLR4 in fetal membranes increased with pregnancy, and the expression level of TLR4 controlled the expression of cytokines, suggesting that the expression of the receptor is related to the intensity of its effect. In this study, LPS upregulated TLR4 expression, and CAPE significantly inhibited LPS-induced upregulation of TLR4 expression, suggesting that activity of $\mathrm{NF}-\kappa \mathrm{B}$ has an important regulatory role on TLR4 expression. In addition, the binding of TLR4 to ligand can also activate NF- $\kappa \mathrm{B}$, whereas NF- $\mathrm{B}$ regulates TLR4 expression. There may be a positive feedback regulation mechanism between them. Upregulation of TLR4 expression after $\mathrm{NF}-\kappa \mathrm{B}$ activation enhances LPS-mediated TLR4/NF- $\kappa \mathrm{B}$ signaling, which aggravates LPS-induced cardiomyocyte injury. However, how $\mathrm{NF}-\kappa \mathrm{B}$ regulates TLR4 expression is unclear. It is possible that the nuclear translocation of NF- $\mathrm{NB}$ may promote the transcription of TLR 4 gene, or cytokines downstream NF- $\mathrm{NB}$ stimulate the expression of TLR4. More studies are needed to answer these questions.

In conclusion, activation of TLR4/NF- $\kappa \mathrm{B}$ by LPS positively regulates TLR4 expression. Upregulation of TLR4 may aggravate the damage to NRVMs caused by LPS. TLR4/NF- $\mathrm{B}$ signaling upregulates the expression of $\mathrm{ATG}$ and $\mathrm{AT}_{1}$ receptors in NRVMs, suggesting that TLR4/NF- $\kappa \mathrm{B}-$ mediated activation of the local renin-ATG system is one of the mechanisms involved in the pathogenesis of cardiovascular diseases. $\mathrm{NF}-\kappa \mathrm{B}$ plays a key regulatory role in LPS-mediated effects mentioned above. Intervention with TLR4/NF- $\kappa \mathrm{B}$ signaling may be a new target for the prevention and treatment of left ventricular remodeling or other cardiovascular diseases.

\section{Acknowledgements}

Not applicable.

\section{Funding}

This project was supported by the National Natural Science Foundation of China (no. 30371568).

\section{Availability of data and materials}

The datasets used and/or analyzed during the current study are available from the corresponding author on reasonable request.

\section{Author's contributions}

HJ was responsible for PCR and the writing of the paper. PQ provided ideas of selecting topics and revised the paper. HYW was responsible for conducting experiments and statistical methods. JWW was a major contributor in the collection of data, modification of pictures and statistical analysis. DYL was responsible for reviewing literature and summing up the data. NN was responsible for cell culture. GHL was responsible for assisting $\mathrm{HJ}$ to perform the experi-ment and collection and assembly of data. All authors read and approved the final manuscript.

\section{Ethics approval and consent to participate}

This study was approved by the Ethics Committee of the Second Affiliated Hospital of Dalian Medical University (Dalian, China).

\section{Patient consent for publication}

Not applicable.

\section{Competing interests}

The authors declare that they have no competing interests.

\section{References}

1. Medzhitov R, Preston-Hurlburt P and Janeway CA Jr: A human homologue of the Drosophila Toll protein signals activation of adaptive immunity. Nature 388: 394-397, 1997. 
2. Frantz S, Kobzik L, Kim YD, Fukazawa R, Medzhitov R, Lee RT and Kelly RA: Toll4 (TLR4) expression in cardiac myocytes in normal and failing myocardium. J Clin Invest 104: 271-280, 1999.

3. Liu L, Wang Y, Cao ZY, Wang MM, Liu XM, Gao T, Hu QK, Yuan WJ and Lin L: Upregulated TLR4 in cardiomyocytes exacerbates heart failure after long-term myocardial infarction. J Cell Mol Med 19: 2728-2740, 2015

4. Yang Y, Lv J, Jiang S, Ma Z, Wang D, Hu W, Deng C, Fan C, Di S, Sun Y, et al: The emerging role of Toll-like receptor 4 in myocardial inflammation. Cell Death Dis 7: e2234, 2016.

5. Ehrentraut H, Felix Ehrentraut S, Boehm O, El Aissati S, Foltz F, Goelz L, Goertz D, Kebir S, Weisheit C, Wolf M, et al: Tlr4 deficiency protects against cardiac pressure overload induced hyperinflammation. PLoS One 10: e0142921, 2015.

6. Ha T, Li Y, Hua F, Ma J, Gao X, Kelley J, Zhao A, Haddad GE, Williams DL and William Browder I: Reduced cardiac hypertrophy in toll-like receptor 4-deficient mice following pressure overload. Cardiovasc Res 68: 224-234, 2005.

7. Ferrario CM: Cardiac remodelling and RAS inhibition. Ther Adv Cardiovasc Dis 10: 162-171, 2016.

8. Li HL, Suzuki J, Bayna E, Zhang FM, Dalle Molle E, Clark A, Engler RL and Lew WY: Lipopolysaccharide induces apoptosis in adult rat ventricular myocytes via cardiac AT(1) receptors. Am J Physiol Heart Circ Physiol 283: H461-H467, 2002.

9. Abareshi A, Norouzi F, Asgharzadeh F, Beheshti F, Hosseini M, Farzadnia M and Khazaei M: Effect of angiotensin-converting enzyme inhibitor on cardiac fibrosis and oxidative stress status in lipopolysaccharide-induced inflammation model in rats. Int J Prev Med 8: 69, 2017.

10. Tapping RI, Akashi S, Miyake K, Godowski PJ and Tobias PS Toll-like receptor 4, but not toll-like receptor 2, is a signaling receptor for Escherichia and Salmonella lipopolysaccharides. J Immunol 165: 5780-5787, 2000.
11. Cervenka L, Vanecková I, Husková Z, Vanourková Z, Erbanová M, Thumová M, Skaroupková P, Opocenský M, Malý J, Chábová VC, et al: Pivotal role of angiotensin II receptor subtype $1 \mathrm{~A}$ in the development of two-kidney, one-clip hypertension: Study in angiotensin II receptor subtype 1A knockout mice. J Hypertens 26: 1379-1389, 2008.

12. Boza P, Ayala P, Vivar R, Humeres C, Cáceres FT, Muñoz C, García L, Hermoso MA and Díaz-Araya G: Expression and function of toll-like receptor 4 and inflammasomes in cardiac fibroblasts and myofibroblasts: IL-1 $\beta$ synthesis, secretion, and degradation. Mol Immunol 74: 96-105, 2016.

13. Jones WK, Brown M, Ren X, He S and McGuinness M: NF-kappaB as an integrator of diverse signaling pathways: The heart of myocardial signaling? Cardiovasc Toxicol 3: 229-254, 2003.

14. An H, Yu Y, Zhang M, Xu H, Qi R, Yan X, Liu S, Wang W, Guo Z, Guo J, et al: Involvement of ERK, p38 and NF-kappaB signal transduction in regulation of TLR2, TLR4 and TLR9 gene expression induced by lipopolysaccharide in mouse dendritic cells. Immunology 106: 38-45, 2002.

15. Harju K, Ojaniemi M, Rounioja S, Glumoff V, Paananen R, Vuolteenaho R and Hallman M: Expression of toll-like receptor 4 and endotoxin responsiveness in mice during perinatal period. Pediatr Res 57: 644-648, 2005.

This work is licensed under a Creative Commons

Attribution-NonCommercial-NoDerivatives 4.0 International (CC BY-NC-ND 4.0) License. 